\title{
Changing temperature and rainfall gradients in the British Uplands
}

\author{
T. P. Burt ${ }^{1}$, J. Holden ${ }^{2, *}$ \\ ${ }^{1}$ Department of Geography, Durham University, Durham DH1 3LE, UK \\ ${ }^{2}$ School of Geography, University of Leeds, Leeds LS2 9JT, UK
}

\begin{abstract}
Climate change is likely to be experienced differently at higher elevations than in lowland areas. Observations of recent change can increase understanding of how changes will be realised. We examined changes in temperature lapse rates and rainfall gradients between pairs of stations, lowland and upland, across the UK. Seasonal and annual changes were investigated, because there may well be shorter-term changes which are not reflected in the overall annual average. Significant changes in both temperature and rainfall were observed, but the pattern of changes was spatially and seasonally variable across the UK. In general, temperature changes were stronger in winter than in summer, and minima rose more than maxima in the uplands, whereas the changes were similar between minima and maxima in the lowlands. Most (but not all) upland stations showed significant increases in rainfall totals in winter that were greater than those experienced in the nearby lowlands. However, variations in seasonal trends of lapse rates and rainfall gradients are sufficiently large to warrant concern about existing climate change projections and the downscaling of regional and global climate models. Specifically, analysis at an annual time scale may mask important seasonal patterns. For countries where the data network is dominated by lowland stations but a significant proportion of the landscape is upland, this poses a problem for estimating temperature change over a large proportion of the landscape. Given the lack of a consistent pattern of changes, we advocate an extension of climate monitoring in the uplands in order to detail ongoing climate change in the different upland areas.
\end{abstract}

KEY WORDS: Lapse rates $\cdot$ Precipitation $\cdot$ Time series $\cdot$ Long-term records

\section{INTRODUCTION}

Some regional climate models predict a warming of about $3^{\circ} \mathrm{C}$ by 2100 (compared with 1961-1990) for many areas of northern Europe (Christensen et al. 2007). However, it has been suggested that, due to changing surface-based lapse rates, upland areas may not warm in parallel with the lowlands (Pepin 1995, Diaz \& Bradley 1997, Pepin \& Lundquist 2008). Although there are many long-term instrumental temperature records such as those at Durham in northern England (available since 1850), these are largely confined to lowland areas. Inconsistent changes in surface lapse rates (i.e. the rate at which temperature declines with altitude near the ground surface) have been found in the relatively short instrumental records of the Euro- pean Alps (Beniston et al. 1994, Beniston \& Rebetez 1996) and the Rocky Mountains (Pepin 2000). Diaz \& Bradley (1997) examined 116 global stations and found that some high-elevation stations showed enhanced warming over the $\sim 30$ yr to 1990 , although there were few long-term records for neighbouring upland-lowland pairs. Liu \& Chen (2000) have reported steepening surface lapse rates in the Tibetan Plateau between the mid 1950s and the $1990 \mathrm{~s}$ at a rate of $\sim 0.06^{\circ} \mathrm{C}$ decade ${ }^{-1}$ altitudinal $\mathrm{km}^{-1}$. Vuille \& Bradley (2000), on the other hand, have reported declining lapse rates (since lower elevations warmed faster than higher elevations) in the Andes between 1959 and 1998 at a mean rate of change of $0.025^{\circ} \mathrm{C}_{\text {decade }}$ deltitudinal $^{-1} \mathrm{~km}^{-1}$.

Warming in the UK uplands is particularly important because the soils are predominately organic and peaty 
(Holden et al. 2007b); these soils are significant and sensitive carbon stores (Hilbert et al. 2000, Bradley et al. 2005), which may become net sources of carbon under climate change (Worrall et al. 2004). These uplands also contain internationally important ecological habitats and are source areas for water supply (Holden et al. 2007b). Many of the uplands in the UK have mean winter temperatures close to $0^{\circ} \mathrm{C}$ and, as such, are zones of significant freeze-thaw activity, thus impacting geomorphological processes (Holden et al. 2007a). The UK uplands are also susceptible to snow accumulations, which can be a major source of flooding if a warm Atlantic air mass moves across the landscape rapidly, melting the snow; most of the record riverine floods in Britain have originated from rain-onsnow episodes. Thus, changing temperature and precipitation patterns in the uplands are important for geomorphological processes, ecological systems, water resource management and understanding flood risk.

There have been a limited number of studies on changing temperature gradients between the uplands and lowlands in the UK. Holden \& Rose (2010) have shown for one pair of stations in northern England, where a homogenised continuous record was available at the upland station since 1931, that there was significant warming at both stations. However, whereas there was no significant change in the mean annual lapse rate between stations, there was a significant decrease (increase) in winter (summer) half-year lapse rates. Thus, the seasonality of lapse rate change needs to be considered. Work on surface-lapse rate change in the UK has, to date, been of limited spatial extent, focusing only on the hills of the North Pennines in England (Pepin 2001, Holden \& Rose 2010). Thus, there is a need for a wider spatial appraisal of lapse-rate patterns, but long-term data availability is a limiting factor. Where instrumental records of climate exist in the uplands, there is a need to ensure their use in studying trends associated with climate change (Appenzeller et al. 2008) as it may not be accurate to infer upland changes from lowland records. More research is needed using data from a wider network of stations, which is what we tackle for the UK in the present study.

Just as there is limited research on changing lapse rates in upland areas, so is there limited information on changing rainfall gradients. Because increased air temperatures associated with global warming will inevitably lead to increased evaporation and higher water-vapour content in the atmosphere, precipitation must also increase, although the spatial and temporal response is likely to be complex. Most climate models predict increases in both rainfall frequency and intensity at high latitudes in the Northern Hemisphere (Meehl et al. 2007), including northern Europe, where increases in winter rainfall (predominantly from frontal systems) are likely to contribute to higher annual rainfall totals, although total summer rainfall (mainly convective) may decrease somewhat (Christensen et al. 2007). Fowler \& Kilsby (2007) noted that downscaled model output for northern England indicated an increase of 20 to $30 \%$ in mean monthly rainfall in winter (November-March), with a reduction of up to $50 \%$ in summer (May-September). Fowler \& Ekström (2009) provided multi-model ensemble estimates of the impact of climate change on UK seasonal precipitation extremes. Extreme precipitation seems likely to increase across the UK in winter, spring and autumn by 5 to $30 \%$. However, poor model performance means there is less certainty about summer rainfall, with both increases and decreases in extreme precipitation predicted. There has indeed been a widespread shift in the pattern of UK rainfall towards more heavy falls of rain in winter and fewer in summer in recent decades (Osborn et al. 2000, Osborn \& Hulme 2002, Burt \& Horton 2007, Maraun et al. 2008), and these changes are reflected in seasonal rainfall totals. Malby et al. (2007) identified a clear change in the seasonality of orographic rainfall in the Lake District of northern England and speculated that this was related to the incidence of higher-intensity events, but otherwise there has been little attention paid to changes in upland rainfall gradients associated with this changing seasonality of heavy rainfall. These changes in rainfall regime are reflected in trends of river discharge, with increasing high flows in winter especially evident in western Britain (Dixon et al. 2006, Hannaford \& Marsh 2008). For Scotland, an unprecedented flood frequency in the 1980s and 1990s in western rivers has been reported (Black \& Burns 2002).

The aim of the present study was to examine altitudinal changes in near-surface temperature lapse rates and rainfall gradients by using data from upland and lowland stations in the UK. The results will, however, be important to furthering awareness of temperature and rainfall gradients across elevation ranges in other countries. Locations were chosen where upland stations with long records were available for comparison with nearby lowland records. We tested the hypothesis that near-surface lapse rates have changed significantly between upland and lowland stations within particular seasons, even though there may have been no significant annual change. We also tested the hypothesis that there have been increases in rainfall gradients between the uplands and lowlands in the UK and that these changes are more dominant in some seasons. The present study extends the spatial coverage of earlier work on changes in temperature lapse rate from the North Pennines to include Scotland and southwest England, and introduces an examination of changing rainfall gradients. 


\section{METHODS}

\subsection{Study sites}

As there are a large number of lowland stations across the UK with long records of temperature and rainfall, our first priority was to identify the upland stations with suitable complete long-term records with which to perform a regional analysis. Long-term instrumental temperature records for upland stations are particularly rare. We searched for stations that were at an altitude of $\geq 500 \mathrm{~m}$ within the British Atmospheric Data Centre data sets (http://badc.nerc.ac.uk). However, there are only 15 stations that have recorded daily temperature above an altitude of $500 \mathrm{~m}$ in the UK. Of these, only 4 currently operate and only one (Moor House) has a continuous record extending back $>30$ yr. We relaxed our search criteria to include those stations above $400 \mathrm{~m}$ and those with $>25 \mathrm{yr}$ of recent data. This resulted in only Moor House in northern England, Princetown in southwest England and Cairngorm chairlift in northern Scotland being identified. Thus, our station choice was limited entirely by data availability and it was not possible to examine trends for a larger group of upland and lowland stations. Even stretching our search to $320 \mathrm{~m}$ altitude only included one more station: Braemar, in the eastern highlands of Scotland. The locations of the stations used in the present study are shown in Fig. 1.

Details of the temperature stations are outlined in Table 1. For the Cairngorm area in northern Scotland, in addition to the lowland station at Inverness, data were also available from 1991 for the summit of Cairngorm at $1245 \mathrm{~m}$, just $1.5 \mathrm{~km}$ away from the Cairngorm chairlift station. While this is a short-term record and there are several data gaps, it was thought useful to include this high-altitude station for local comparison. Just $10 \mathrm{~km}$ away from Cairngorm chairlift there is also a station at Aviemore at 286 m, operational since 1982, which was used for an intermediate altitudinal comparison. In the North Pennines, the UK's longest upland instrumental temperature record is located at Moor House (556 $\mathrm{m}$ altitude) and has been running since 1931. This record has already been homogenised and compared with the Durham record, which is $53 \mathrm{~km}$ to the east at $102 \mathrm{~m}$ altitude, by Holden \& Rose (2010). However, they did not analyse differences between all 4 seasons at the 2 stations. Additionally, 2 further stations were included in the North Pennines analysis: Newton Rigg and Great Dunn Fell. Newton Rigg (169 $\mathrm{m}$ altitude) is a lowland station $24 \mathrm{~km}$ to the west of Moor House; its location therefore allows us to examine lapse-rate differences to the east and west of the upland Moor House station. Just as at Cairngorm, there are also some data available from a local station

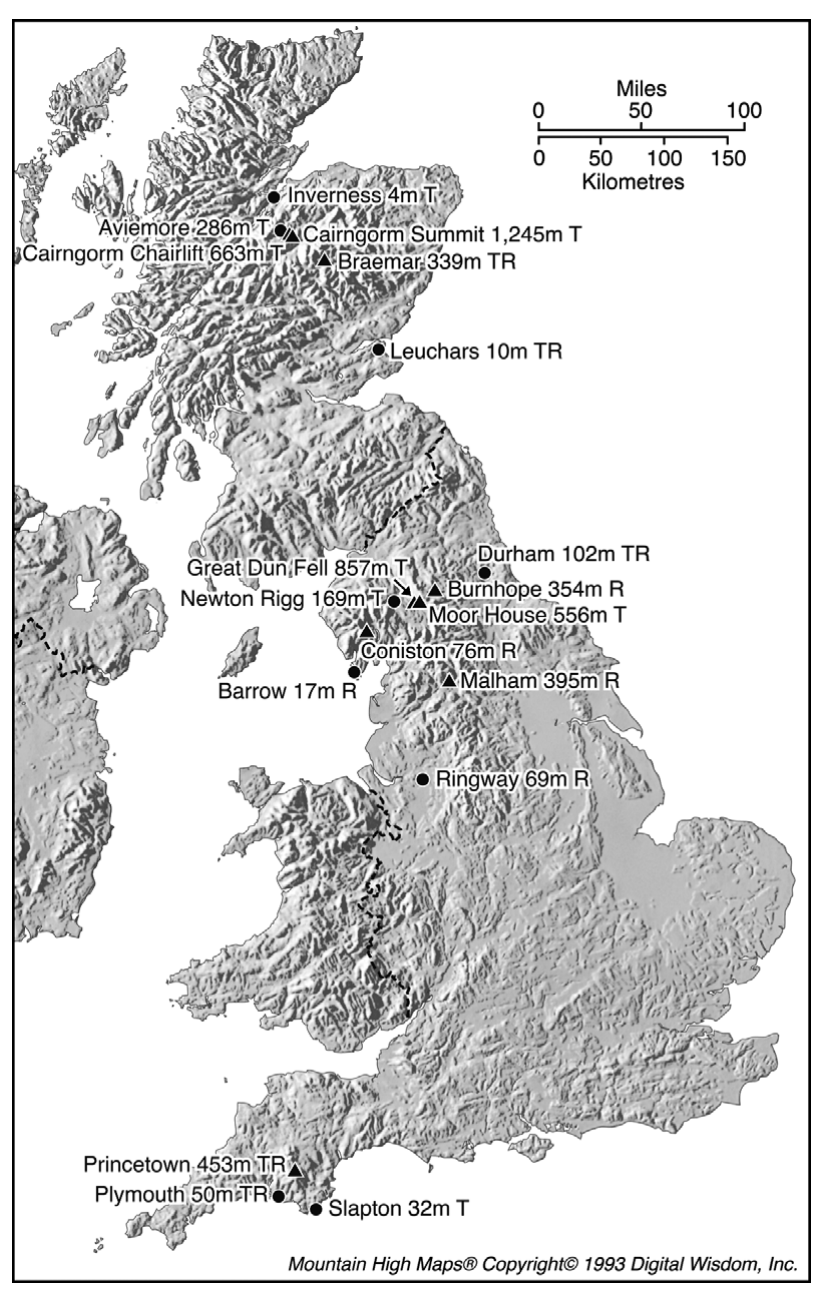

Fig. 1. Observation stations. Gauges within an upland setting are indicated with a triangle and lowland stations with a circle. The altitude of each station is provided next to its name.

$\mathrm{T}$ : temperature data analysed; R: rainfall data analysed

(4 km away) much higher than Moor House at Great Dun Fell (857 $\mathrm{m}$ altitude), and so for local lapse-rate comparison it was decided to include this station in some of the analyses. There are no suitable long-term temperature records in upland Wales. In southwest England there is only one long-term upland record, at Princetown, but this ceased operation in 1997 and so the latter part of this record is missing when compared with the other stations described above. The Princetown record is also incomplete, with a number of months and years missing from the data period. However, because it is the only long-term record in the region, the station was retained in our analyses, but it should be noted that the southwest England temperature analysis may not be as robust when compared with that performed for the other regions. 
Table 1. Details of stations used in the present study. Daily maximum and minimum temperatures were used to derive daily means. Dates are for those data used in the present study; the records of some stations started earlier than the dates given

\begin{tabular}{|c|c|c|c|c|c|c|c|}
\hline Station & $\begin{array}{c}\text { Temperature }(T \\
\text { or rainfall }(R)\end{array}$ & Coordinates & Altitude (m) & Start date & End date & $\begin{array}{l}\text { Mean annual } \\
\text { temperature }\left({ }^{\circ} \mathrm{C}\right)\end{array}$ & $\begin{array}{l}\text { Mean annual } \\
\text { rainfall (mm) }\end{array}$ \\
\hline Cairngorm summit & $\mathrm{T}$ & $57.116^{\circ} \mathrm{N}, 3.642^{\circ} \mathrm{W}$ & 1245 & 1992 & 2009 & 1.6 & \\
\hline Cairngorm chairlift & $\mathrm{T}$ & $57.133^{\circ} \mathrm{N}, 3.668^{\circ} \mathrm{W}$ & 663 & 1982 & 2009 & 5.6 & \\
\hline Aviemore & $\mathrm{T}$ & $57.206^{\circ} \mathrm{N}, 3.827^{\circ} \mathrm{W}$ & 286 & 1982 & 2009 & 7.5 & \\
\hline Inverness & $\mathrm{T}$ & $57.487^{\circ} \mathrm{N}, 4.223^{\circ} \mathrm{W}$ & 4 & 1982 & 2009 & 9.0 & \\
\hline Braemar & $\mathrm{T}, \mathrm{R}$ & $57.006^{\circ} \mathrm{N}, 3.397^{\circ} \mathrm{W}$ & 339 & 1959 & 2009 & 6.5 & 924 \\
\hline Leuchars & $\mathrm{T}, \mathrm{R}$ & $56.377^{\circ} \mathrm{N}, 2.862^{\circ} \mathrm{W}$ & 10 & 1959 & 2009 & 8.5 & 669 \\
\hline Moor House & $\mathrm{T}$ & $54.690^{\circ} \mathrm{N}, 2.375^{\circ} \mathrm{W}$ & 556 & 1959 & 2006 & 5.3 & 2012 \\
\hline Great Dun Fell & $\mathrm{T}$ & $54.684^{\circ} \mathrm{N}, 2.448^{\circ} \mathrm{W}$ & 847 & $\begin{array}{l}1963 \\
1994\end{array}$ & $\begin{array}{l}1972 \\
2006\end{array}$ & 3.9 & \\
\hline Newton Rigg & $\mathrm{T}$ & $54.670^{\circ} \mathrm{N}, 2.786^{\circ} \mathrm{W}$ & 169 & 1959 & 2006 & 8.4 & \\
\hline Durham & $\mathrm{T}, \mathrm{R}$ & $54.768^{\circ} \mathrm{N}, 1.585^{\circ} \mathrm{W}$ & 102 & 1959 & 2006 & 8.8 & 649 \\
\hline Princetown & $\mathrm{T}, \mathrm{R}$ & $50.548^{\circ} \mathrm{N}, 4.001^{\circ} \mathrm{W}$ & 453 & $\begin{array}{l}1936 \mathrm{~T} \\
1912 \mathrm{R}\end{array}$ & $\begin{array}{l}1997 \mathrm{~T} \\
2006 \mathrm{R}\end{array}$ & 8.1 & 2058 \\
\hline Slapton & $\mathrm{T}$ & $50.292^{\circ} \mathrm{N}, 3.651^{\circ} \mathrm{W}$ & 32 & 1960 & 1997 & 10.8 & 1064 \\
\hline Plymouth & $\mathrm{T}, \mathrm{R}$ & $50.354^{\circ} \mathrm{N}, 4.121^{\circ} \mathrm{W}$ & 50 & $\begin{array}{l}1936 \mathrm{~T} \\
1912 \mathrm{R}\end{array}$ & $\begin{array}{l}1997 \mathrm{~T} \\
2000 \mathrm{R}\end{array}$ & 10.8 & 1001 \\
\hline Malham & $\mathrm{R}$ & $54.100^{\circ} \mathrm{N}, 2.162^{\circ} \mathrm{W}$ & 381 & 1961 & 2000 & & 1508 \\
\hline Ringway & $\mathrm{R}$ & $53.356^{\circ} \mathrm{N}, 2.279^{\circ} \mathrm{W}$ & 69 & 1961 & 2000 & & 809 \\
\hline Burnhope & $\mathrm{R}$ & $54.770^{\circ} \mathrm{N}, 2.250^{\circ} \mathrm{W}$ & 354 & 1961 & 2000 & & 1303 \\
\hline Coniston & $\mathrm{R}$ & $54.308^{\circ} \mathrm{N}, 3.109^{\circ} \mathrm{W}$ & 76 & 1961 & 2000 & & 2489 \\
\hline Barrow & $\mathrm{R}$ & $54.126^{\circ} \mathrm{N}, 3.212^{\circ} \mathrm{W}$ & 17 & 1961 & 2000 & & 984 \\
\hline
\end{tabular}

It is quite common for a station to collect rainfall data but not temperature and vice versa; therefore, the stations used for temperature and rainfall analysis were often different (Table 1). For rainfall records, there are more upland gauges available to choose from as many are monthly spot gauges requiring less maintenance and cost than daily or sub-daily recording stations, although all the records here are based on daily data. Selection has involved pairs of gauges, one in the uplands and one nearby in the lowlands. The upland areas included for the correlation analysis are as follows (with the upland station given first): Dartmoor (Princetown-Plymouth); South Pennines (Malham-Ringway); North Pennines (Burnhope-Durham); Lake District (Coniston-Barrow); and Cairngorms (Braemar-Leuchars). It should be noted that although the altitudinal difference between the Lake District pair is only $59 \mathrm{~m}$, the Coniston gauge is located with an upland setting, the maximum altitude within $2 \mathrm{~km}$ of the gauge is $550 \mathrm{~m}$ and the gauge is located in a deep valley within the upland massif. By contrast, Barrow is in a lowland coastal setting, and receives on average $1500 \mathrm{~mm}$ less rainfall per year than Coniston.

\subsection{Data analysis}

Temperature data were obtained from the British Atmospheric Data Centre, the UK Environmental
Change Network (for Moor House; www.ecn.ac.uk) and Durham University (www.geography.dur.ac.uk/ projects/weather). Daily maxima and minima were converted to daily means as per the meteorological standard (Holden 2007) and these were used to calculate monthly, seasonal and annual means. Seasonal analysis was conducted using the standard UK meteorological definitions of winter (December-February), spring (March-May), summer (June-August) and autumn (September-November). Trends in maxima, minima and means were compared between stations. Because of the lack of upland data it was decided not to restrict the analysis to the same time periods across the UK. However, within regions the time period for upland-lowland trend comparisons was kept the same. The start date was determined by the earliest possible date for which data were available at the same time for all stations across the upland-lowland analysis.

Rainfall data have been acquired from a variety of sources including the British Atmospheric Data Centre, the Climatic Research Unit (University of East Anglia; www.cru.uea.ac.uk), the Environment Agency (www.environment-agency.gov.uk), the Field Studies Council (Slapton) (www.field-studies-council.org/ slaptonley) and Durham University. Data have been compiled into seasonal totals using the standard meteorological seasons as described above. To allow comparison, analyses have focused on the period 1961 to 
2000 , since increases in winter rainfall and decreases in summer rainfall are well documented over this time (Osborn et al. 2000, Osborn \& Hulme 2002, Burt \& Horton 2007, Maraun et al. 2008). To provide a longer-term perspective, the much longer time series for both Plymouth and Princetown from 1912 to 2000 have also been compared. Minor gaps $(<2.5 \%$ of the time) in the rainfall record at Princetown between 1961 and 2000 have been infilled using a nearby gauge located $400 \mathrm{~m}$ away (26 $\mathrm{m}$ higher in altitude). A regression equation was produced for periods when data overlapped between the 2 stations and applied to fill the gaps in the main Princetown gauge $\left(\mathrm{r}^{2}=0.98\right)$. This method therefore does not negate the independence of stations in our analysis because there were effectively 2 stations at the same upland station, which we used to create a homogenised record.

Temperature lapse rates were calculated by subtracting the upland temperature statistic from the lowland temperature statistic and then dividing by the altitudinal difference between the stations to provide a value in ${ }^{\circ} \mathrm{C} \mathrm{km}^{-1}$. Trends in lapse rates over time are given in ${ }^{\circ} \mathrm{C} \mathrm{km}^{-1}$ decade $^{-1}$. Temperature statistics evaluated include mean daily temperature, mean maximum daily temperature and mean minimum daily temperature for annual and seasonal periods. An increasing lapse rate is defined as one where the difference between lowland and upland temperature has increased (hence a positive correlation coefficient with time), whereas a decreasing lapse rate is one where the difference be- tween the upland and lowland temperature has decreased. Actual values were used to calculate the trends. Trends over time (based on the linear gradient of the best-fit line) were determined and tested for significance $(p<0.05)$ by least-squares linear regression using the year as the unit of time. Although Santer et al. (2000) have shown that this could produce slightly different statistical outcomes when compared with other techniques for assessing the trend (e.g. on the basis of minimising absolute deviation between the data and the linear fit), we adopt the least-squares method for consistency of comparison with the majority of earlier publications. The directions of change in trend behaviour between stations should, in any case, be comparable no matter what technique is used. Rainfall gradients and trends were calculated in the same way as for temperature lapse rates, but here only mean seasonal and annual rainfall totals were evaluated over time.

\section{RESULTS AND DISCUSSION}

\subsection{Temperature}

\subsubsection{Northern Scotland}

The annual mean temperature has significantly increased $(p<0.05)$ for Cairngorm chairlift, Aviemore and Inverness since 1982 (Fig. 2) at a rate of 0.50, 0.44 and $0.31^{\circ} \mathrm{C}$ per decade, respectively. Increases in
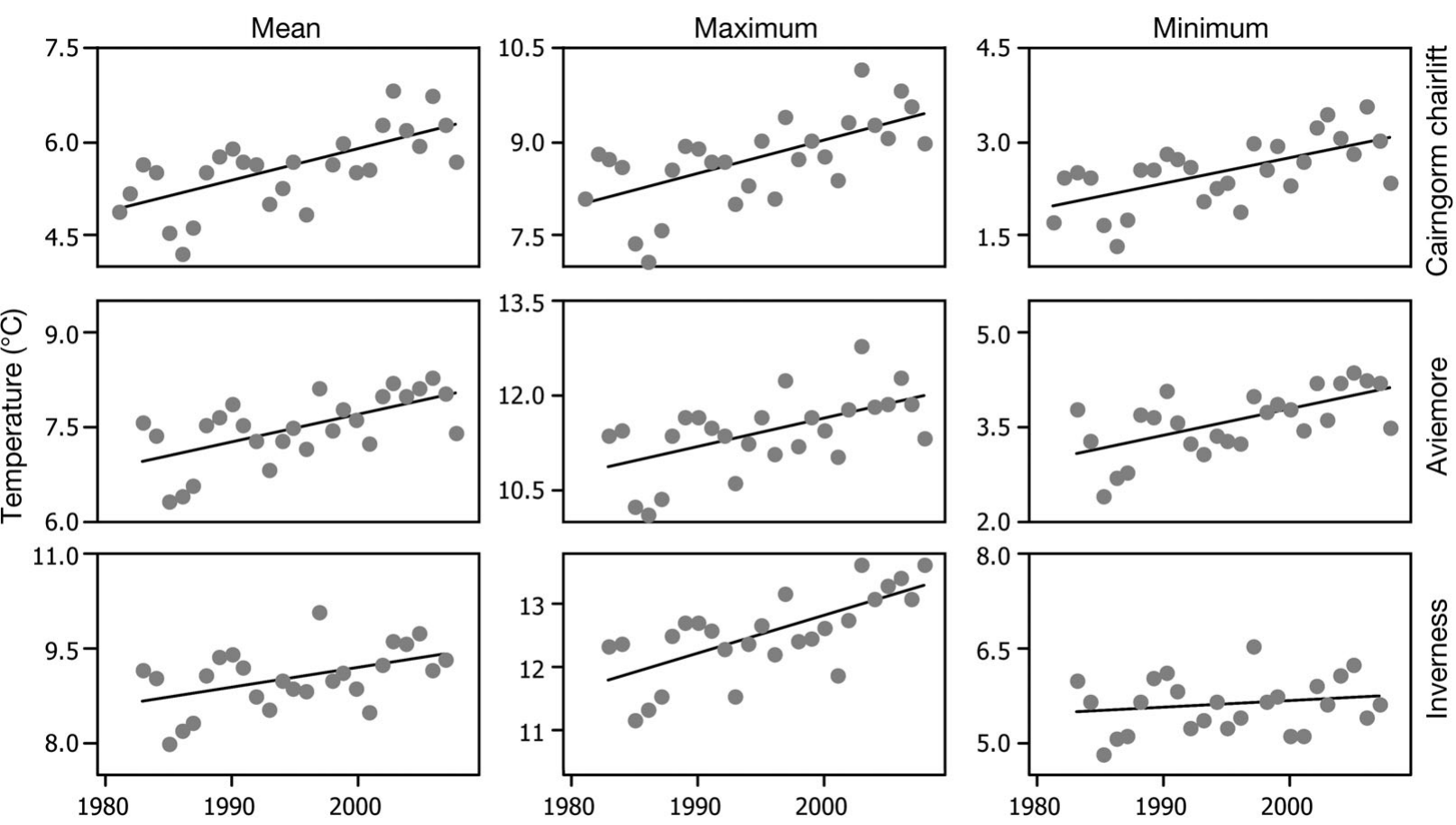

Fig. 2. Mean, mean maximum and mean minimum annual temperatures for Cairngorm chairlift, Aviemore and Inverness. Note that all $y$-axes have the same length of $3.5^{\circ} \mathrm{C}$ 
annual mean maxima were stronger than those for annual mean minima. There were not enough complete yearly data to allow a robust analysis of change in mean annual temperature for Cairngorm summit. Annual mean maxima and minima have significantly increased at all stations except for the annual mean minima at Inverness. Table 2 provides details of the trend in seasonal mean maxima, seasonal mean minima and seasonal mean temperature for Cairngorm chairlift, Aviemore and Inverness between 1982 and 2009. No significant changes were observed in the summer. There were significant increases in means, maxima and minima in all other seasons at Cairngorm chairlift. Changes in the autumn generally appeared to be strongest. There were no significant changes in minima over time at Inverness, but there were increases in maxima in all seasons except summer. This translated into there being no significant trend with time for mean temperature except in the winters, which have warmed. The record for Cairngorm summit is short and so was not included in Table 2; the only significant change found within the Cairngorm summit data set since 1991 was an increase in the autumn mean minimum temperature.

Annual mean lapse rates significantly decreased $(\mathrm{p}<$ 0.05 ) between Inverness and Cairngorm chairlift and

Table 2. Correlation coefficients and gradients of change over time $\left(b,{ }^{\circ} \mathrm{C}\right.$ decade $\left.{ }^{-1}\right)$ in seasonal mean maxima, mean minima and mean temperature at the northern Scotland stations, 1983-2009. Cairngorm chairlift, Aviemore and Inverness are upland, intermediate and lowland stations, respectively. Data are significant at $p<0.05$ unless otherwise indicated. NS: not significant; ND: not determined

\begin{tabular}{|c|c|c|c|c|c|c|}
\hline \multirow{2}{*}{ Station } & \multicolumn{3}{|c|}{$-\mathrm{r}$} & \multicolumn{2}{|c|}{$-\mathrm{b}$} & \multirow[b]{2}{*}{ Mean } \\
\hline & Max. & Min. & Mean & Max. & Min. & \\
\hline \multicolumn{7}{|l|}{ Winter } \\
\hline $\begin{array}{l}\text { Cairngorm } \\
\text { chairlift }\end{array}$ & 0.45 & 0.43 & 0.50 & 0.64 & 0.47 & 0.57 \\
\hline Aviemore & 0.38 & NS & NS & 0.48 & NS & NS \\
\hline Inverness & 0.40 & NS & NS & 0.48 & NS & NS \\
\hline \multicolumn{7}{|l|}{ Spring } \\
\hline $\begin{array}{l}\text { Cairngorm } \\
\text { chairlift }\end{array}$ & 0.49 & 0.44 & 0.57 & 0.69 & 0.45 & 0.69 \\
\hline Aviemore & 0.53 & 0.49 & 0.55 & 0.73 & 0.40 & 0.57 \\
\hline Inverness & 0.50 & NS & NS & 0.49 & ND & ND \\
\hline \multicolumn{7}{|l|}{ Summer } \\
\hline $\begin{array}{l}\text { Cairngorm } \\
\text { chairlift }\end{array}$ & NS & NS & NS & ND & ND & ND \\
\hline Aviemore & NS & 0.45 & NS & ND & 0.57 & ND \\
\hline Inverness & NS & NS & NS & ND & ND & ND \\
\hline \multicolumn{7}{|l|}{ Autumn } \\
\hline $\begin{array}{l}\text { Cairngorm } \\
\text { chairlift }\end{array}$ & 0.63 & 0.47 & 0.57 & 0.70 & 0.40 & 0.54 \\
\hline Aviemore & 0.63 & 0.44 & 0.57 & 0.73 & 0.50 & 0.61 \\
\hline Inverness & 0.70 & NS & 0.53 & 0.83 & ND & 0.51 \\
\hline
\end{tabular}

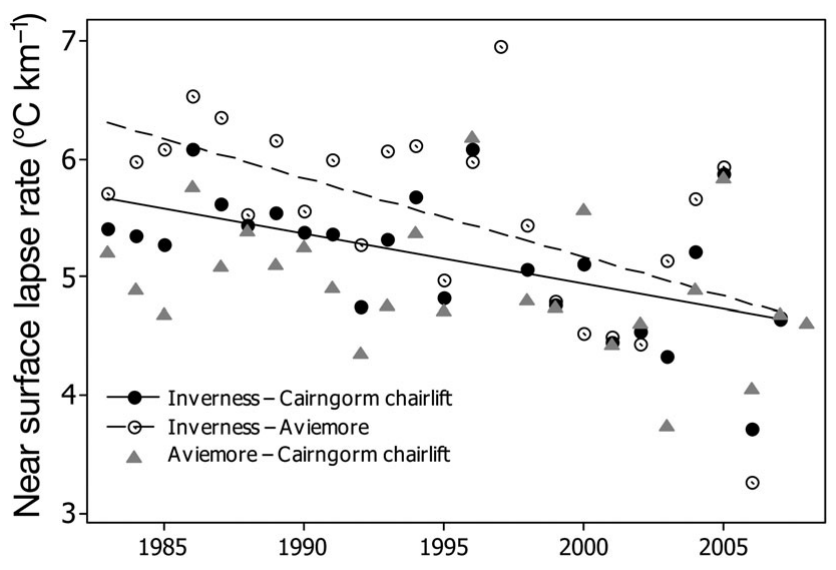

Fig. 3. Mean annual lapse rates between Cairngorm chairlift, Aviemore and Inverness for 1983 to 2008 . Regression lines are shown for the 2 significant trends with $\mathrm{r}^{2}$ of 0.31 for Inverness-Cairngorm chairlift (solid line) and 0.36 for InvernessAviemore (dashed). The gradients are $-0.42^{\circ} \mathrm{C} \mathrm{km}^{-1}$ decade $^{-1}$ for Inverness-Cairngorm chairlift and $-0.67^{\circ} \mathrm{C} \mathrm{km}^{-1}$ decade $^{-1}$ for Inverness-Aviemore

between Inverness and Aviemore (Fig. 3). There were no significant changes between Aviemore and Cairngorm chairlift. The annual mean temperature lapse rates in the region $\left(5.2^{\circ} \mathrm{C} \mathrm{km}^{-1}\right)$ were somewhat lower than those found in central Scotland $\left(8.7^{\circ} \mathrm{C} \mathrm{km} \mathrm{km}^{-1}\right)$, northern England $\left(6.8^{\circ} \mathrm{C} \mathrm{km}^{-1}\right)$ or southwest England $\left(6.7^{\circ} \mathrm{C} \mathrm{km}^{-1}\right)$. When split by season and by mean maxima and minima, no significant correlations with year were observed for mean temperature lapse rates in summer or autumn, whereas significant correlations of mean temperature lapse rate with time were observed in winter and spring for Inverness-Aviemore and in spring for Inverness-Cairngorm and Aviemore-Cairngorm (Table 3).

There were too many gaps in the data record for Cairngorm summit to perform a fully paired annual or seasonal analysis, so only days for which there were data were compared between Cairngorm summit and Cairngorm chairlift. Data were available for $88 \%$ of days between 1992 and 2009. Using this approach indicated that there was a significant decrease in autumn minima lapse rates, but no significant change for minima, maxima or means in any other season.

\subsubsection{Central Scotland}

For the Braemar-Leuchars station pairing in central Scotland, the analysis showed that there was a significant annual warming at both stations, but no significant change in annual mean lapse rate (Table 4). In fact, there was significant warming in mean maxima, mean minima and mean temperature since 1959 in all seasons and for both stations except for summer maxima at 
Table 3. Correlation coefficients and gradients of change $\left(\mathrm{b}^{\circ}{ }^{\circ} \mathrm{C} \mathrm{km} \mathrm{km}^{-1} \mathrm{decade}^{-1}\right)$ in lapse rates in seasonal mean maxima, mean minima and mean temperature over time at the northern Scotland stations, 1983-2009. Cairngorm chairlift, Aviemore and Inverness are upland, intermediate and lowland stations, respectively. Data are significant at $p<0.05$ unless otherwise indicated. NS: not significant; ND: not determined

\begin{tabular}{|c|c|c|c|c|c|c|}
\hline \multirow{2}{*}{ Station } & \multicolumn{3}{|c|}{$-\mathrm{r}$} & \multicolumn{2}{|c|}{$-\mathrm{b}$} & \multirow[b]{2}{*}{ Mean } \\
\hline & Max. & Min. & Mean & Max. & Min. & \\
\hline \multicolumn{7}{|l|}{ Winter } \\
\hline Inverness-Cairngorm chairlift & NS & NS & NS & ND & ND & ND \\
\hline Inverness-Aviemore & -0.38 & -0.42 & -0.50 & -1.23 & -1.13 & -0.85 \\
\hline Aviemore-Cairngorm chairlift & NS & NS & NS & ND & ND & ND \\
\hline \multicolumn{7}{|l|}{ Spring } \\
\hline Inverness-Cairngorm chairlift & NS & -0.53 & -0.53 & ND & -0.56 & -0.58 \\
\hline Inverness-Aviemore & NS & -0.64 & -0.43 & ND & -1.74 & -2.48 \\
\hline Aviemore-Cairngorm chairlift & -0.43 & NS & -0.44 & -0.42 & ND & -0.50 \\
\hline \multicolumn{7}{|l|}{ Summer } \\
\hline Inverness-Cairngorm chairlift & NS & NS & NS & ND & ND & ND \\
\hline Inverness-Aviemore & +0.56 & -0.61 & NS & +1.17 & -1.13 & ND \\
\hline Aviemore-Cairngorm chairlift & -0.51 & NS & NS & -0.64 & ND & ND \\
\hline \multicolumn{7}{|l|}{ Autumn } \\
\hline Inverness-Cairngorm chairlift & NS & NS & NS & ND & ND & ND \\
\hline Inverness-Aviemore & NS & NS & NS & ND & ND & ND \\
\hline Aviemore-Cairngorm chairlift & NS & NS & NS & ND & ND & ND \\
\hline
\end{tabular}

Table 4. Correlation coefficients and rates of change over time $\left(\mathrm{b},{ }^{\circ} \mathrm{C}\right.$ decade ${ }^{-1}$, or ${ }^{\circ} \mathrm{C}$ decade ${ }^{-1} \mathrm{~km}^{-1}$ for lapse rate) in seasonal and annual mean maxima, mean minima and mean temperature for the central Scotland stations, 1959-2009. Braemar is an upland station, whereas Leuchars is a lowland station. Data are significant at $p<0.05$ unless otherwise indicated. ${ }^{*} p<0.1$; NS: not significant; ND: not determined

\begin{tabular}{|c|c|c|c|c|c|c|}
\hline \multirow{2}{*}{ Station } & \multirow{2}{*}{ Max. } & \multirow{2}{*}{$\begin{array}{c}\mathrm{r}- \\
\text { Min. }\end{array}$} & \multirow[b]{2}{*}{ Mean } & \multirow{2}{*}{ Max. } & \multirow{2}{*}{$\begin{array}{c}-\mathrm{b}- \\
\text { Min. }\end{array}$} & \multirow[b]{2}{*}{ Mean } \\
\hline & & & & & & \\
\hline \multicolumn{7}{|l|}{ Winter } \\
\hline Braemar & 0.39 & 0.39 & 0.40 & 0.34 & 0.41 & 0.37 \\
\hline Leuchars & 0.42 & 0.38 & 0.44 & 0.32 & 0.27 & 0.30 \\
\hline Leuchars-Braemar lapse rate & NS & -0.30 & $-0.28^{*}$ & ND & -0.43 & -0.21 \\
\hline \multicolumn{7}{|l|}{ Spring } \\
\hline Braemar & 0.34 & 0.35 & 0.40 & 0.28 & 0.19 & 0.24 \\
\hline Leuchars & 0.40 & 0.33 & 0.39 & 0.24 & 0.17 & 0.20 \\
\hline Leuchars-Braemar lapse rate & NS & NS & NS & & & \\
\hline \multicolumn{7}{|l|}{ Summer } \\
\hline Braemar & NS & 0.46 & 0.32 & ND & 0.19 & 0.18 \\
\hline Leuchars & 0.40 & 0.49 & 0.37 & 0.25 & 0.20 & 0.24 \\
\hline Leuchars-Braemar lapse rate & NS & NS & $0.25^{*}$ & ND & ND & -0.15 \\
\hline \multicolumn{7}{|l|}{ Autumn } \\
\hline Braemar & 0.30 & 0.32 & 0.34 & 0.18 & 0.18 & 0.18 \\
\hline Leuchars & 0.39 & 0.31 & 0.47 & 0.21 & 0.17 & 0.19 \\
\hline Leuchars-Braemar lapse rate & NS & NS & NS & & & \\
\hline \multicolumn{7}{|l|}{ Annual } \\
\hline Braemar & 0.54 & 0.63 & 0.62 & 0.25 & 0.26 & 0.26 \\
\hline Leuchars & 0.62 & 0.64 & 0.65 & 0.29 & 0.25 & 0.27 \\
\hline Leuchars-Braemar lapse rate & NS & NS & NS & & & \\
\hline
\end{tabular}

Braemar. There was, however, a slight decrease in winter mean lapse rate and a concomitant increase in summer mean lapse rate $(p<0.1)$. There was a significant $(\mathrm{p}<0.05)$ decrease in winter minima lapse rate, which declined at a rate of $0.43^{\circ} \mathrm{C} \mathrm{km}^{-1}$ decade $^{-1}$.

\subsubsection{North Pennines}

Unlike the Scottish stations, the trend for increasing minima was greater than that for increasing maxima at Moor House, but was greater for increasing maxima at Newton Rigg. The trends in lapse rate over time are shown in Table 5. For the west lowland to upland pairing of Newton Rigg and Moor House, there was a significant decrease in the lapse rate for minima in all seasons. The trend was only significant in autumn and winter, not for the year as a whole; therefore, no annual change in lapse rate can be seen between Newton Rigg and Moor House. For the east lowland to upland pairing of Durham and Moor House there was also no significant annual trend in mean temperature lapse rate. However, spring and summer had significantly increased mean temperature lapse rates. The direction of change is for a decrease in mean temperature lapse rates in the autumn and winter, although the trend was not significant. The east lowland and west lowland comparison to the Pennine upland station is therefore similar in terms of directions of change (i.e. autumn and winter decreased lapse rate and spring and summer increased lapse rate), with the significant trends being observed in autumn and winter for the Newton RiggMoor House pair, and spring and summer for the Durham-Moor House pair. Thus, there is an important divergence between autumn/winter and spring/ summer mean temperature lapse rates (Fig. 4). The trends shown demonstrate how differences between autumn/ winter and spring/summer mean temperature lapse rates have increased over time. However, these seasonal changes in lapse rates effectively cancel out at the annual level. Hence, examination of 
Table 5. Correlation coefficients and gradients of change over time $\left(\mathrm{b}^{\circ}{ }^{\circ} \mathrm{C}\right.$ decade ${ }^{-1} \mathrm{~km}^{-1}$ ) in seasonal and annual mean maxima, mean minima and mean temperature at the North Pennine stations, 1959-2006. Great Dun Fell data were only available for 1963-1972 and 1994-2006. Moor House and Great Dun Fell are upland stations, Newton Rigg and Durham are lowland stations. Data are significant at $\mathrm{p}<0.05$ unless otherwise indicated. ${ }^{*} \mathrm{p}<0.1$; NS: not significant; ND: not determined

\begin{tabular}{|c|c|c|c|c|c|c|}
\hline \multirow[t]{2}{*}{ Station } & \multicolumn{3}{|c|}{$-\mathrm{r}$} & \multirow{2}{*}{\multicolumn{2}{|c|}{$\begin{array}{l}\bar{b}- \\
\text { Max. Min. }\end{array}$}} & \multirow[b]{2}{*}{ Mean } \\
\hline & Max. & Min. & Mean & & & \\
\hline \multicolumn{7}{|l|}{ Winter } \\
\hline Newton Rigg-Moor House & NS & -0.52 & -0.36 & ND & -0.62 & -0.21 \\
\hline Durham-Moor House & $0.28^{*}$ & -0.43 & NS & 0.18 & -0.44 & ND \\
\hline Durham-Newton Rigg & NS & NS & NS & ND & ND & ND \\
\hline Moor House-Great Dun Fell & -0.52 & NS & NS & -0.65 & ND & ND \\
\hline \multicolumn{7}{|l|}{ Spring } \\
\hline Newton Rigg-Moor House & NS & $-0.29^{*}$ & * NS & ND & -0.26 & ND \\
\hline Durham-Moor House & NS & NS & 0.46 & ND & ND & 0.15 \\
\hline Durham-Newton Rigg & NS & 0.39 & NS & ND & 1.49 & ND \\
\hline Moor House-Great Dun Fell & NS & -0.55 & -0.52 & ND & -0.69 & -0.58 \\
\hline \multicolumn{7}{|l|}{ Summer } \\
\hline Newton Rigg-Moor House & NS & -0.44 & NS & ND & -0.23 & ND \\
\hline Durham-Moor House & NS & NS & 0.40 & ND & ND & 0.15 \\
\hline Durham-Newton Rigg & NS & 0.48 & NS & ND & 2.09 & ND \\
\hline Moor House-Great Dun Fell & NS & NS & NS & ND & ND & ND \\
\hline \multicolumn{7}{|l|}{ Autumn } \\
\hline Newton Rigg-Moor House & NS & -0.65 & -0.40 & ND & -0.57 & -0.23 \\
\hline Durham-Moor House & NS & $-0.31^{*}$ & * NS & ND & -0.15 & ND \\
\hline Durham-Newton Rigg & NS & 0.47 & NS & ND & 2.24 & ND \\
\hline Moor House-Great Dun Fell & NS & 0.41 & NS & ND & 0.69 & ND \\
\hline \multicolumn{7}{|l|}{ Annual } \\
\hline Newton Rigg-Moor House & NS & -0.35 & NS & ND & -0.44 & ND \\
\hline Durham-Moor House & NS & NS & NS & ND & ND & ND \\
\hline Durham-Newton Rigg & NS & 0.45 & NS & ND & 1.64 & ND \\
\hline Moor House-Great Dun Fell & NS & NS & NS & ND & ND & ND \\
\hline
\end{tabular}

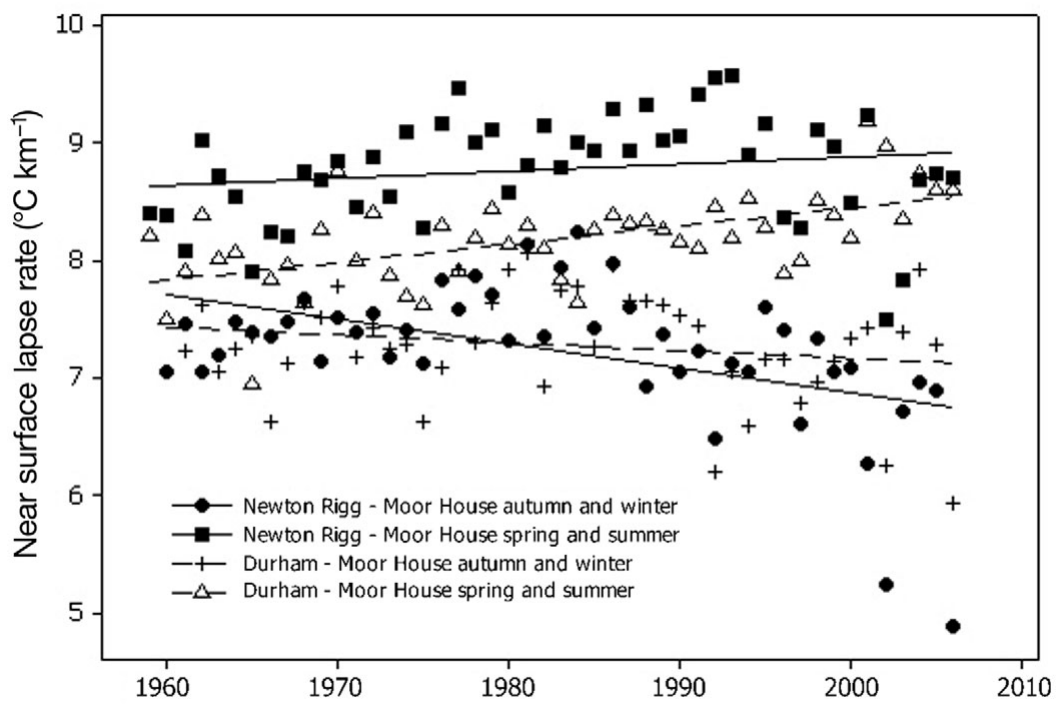

Fig. 4. Lapse rates between Newton Rigg and Moor House and between Durham and Moor House for half-year periods. Best-fit trend lines are shown for each annual temperature records is insufficient to determine changes in lapse rates over time, which may be important on a seasonal level. Interestingly, there was a significant increase in lapse rates over time for minima (except in winter) between the west and east lowland stations of Newton Rigg and Durham, although it should be noted that there is only a $67 \mathrm{~m}$ altitudinal difference between the 2 stations. This, in combination with the trends shown in Table 6, suggests that minima have increased more rapidly at Durham to the east of the Pennine uplands than at Newton Rigg to the west of the Pennines. This may reflect changes in the frequency and/or characteristics of milder westerly air masses affecting the region to the east of the Pennine hills. There were no significant differences in mean or maximum temperature lapse rates between Durham and Newton Rigg.

\subsubsection{Southwest England}

In southwest England, the record for the upland station at Princetown ends in 1997 and so does not extend into the very warm recent years. From 1936 to 1997 there was no significant trend over time in mean annual temperature or mean temperature in any season (Table 7). The only significant warming observed was in annual mean minima. It should be noted, however, that there are several gaps in the Princetown record, with limited data for 1952, 1953 and 1963, and no data for 1958 to 1962 inclusive. These gaps were not infilled for analysis. Significant annual warming has been observed at Plymouth since 1936 and at Slapton since 1960. At Plymouth, mean temperatures have not warmed in the summer months; at Slapton, over the shorter 1960-1997 period, they did not warm significantly in the spring months (although the decadal analysis of Burt \& Horton [2001] showed a steady rise for mean maximum temperatures in spring over this period). The result of the seasonal and annual mean temperature warming at Ply- 
Table 6. Correlation coefficients and gradients of change over time $\left(\mathrm{b},{ }^{\circ} \mathrm{C}\right.$ decade $\left.^{-1}\right)$ in seasonal and annual mean maxima, mean minima and mean temperature at the North Pennine stations, 1959-2006. Moor House and Great Dun Fell are upland stations, whereas Durham and Newton Rigg are lowland stations. Great Dun Fell data were only available for 19631972 and 1994-2006. Data are significant at $p<0.05$ unless otherwise indicated. ${ }^{*} p<0.1$; NS: not significant; ND: not determined

\begin{tabular}{|c|c|c|c|c|c|c|}
\hline \multirow[t]{2}{*}{ Station } & \multicolumn{3}{|c|}{ I } & \multicolumn{2}{|c|}{$-b$} & \multirow[b]{2}{*}{ Mean } \\
\hline & Max. & Min. & Mean & Max. & Min. & \\
\hline \multicolumn{7}{|l|}{ Winter } \\
\hline Moor House & 0.40 & 0.55 & 0.44 & 0.33 & 0.51 & 0.41 \\
\hline Durham & 0.45 & 0.43 & 0.42 & 0.44 & 0.37 & 0.38 \\
\hline Newton Rigg & 0.47 & 0.31 & 0.40 & 0.41 & 0.27 & 0.34 \\
\hline Great Dun Fell & 0.74 & 0.58 & 0.72 & 0.55 & 0.33 & 0.47 \\
\hline \multicolumn{7}{|l|}{ Spring } \\
\hline Moor House & NS & 0.32 & $0.26^{*}$ & ND & 0.21 & 0.16 \\
\hline Durham & 0.40 & 0.45 & 0.40 & 0.29 & 0.23 & 0.23 \\
\hline Newton Rigg & 0.42 & $0.24^{*}$ & 0.38 & 0.29 & 0.12 & 0.20 \\
\hline Great Dun Fell & 0.62 & 0.67 & 0.67 & 0.42 & 0.39 & 0.40 \\
\hline \multicolumn{7}{|l|}{ Summer } \\
\hline Moor House & $0.29^{*}$ & 0.59 & 0.34 & 0.21 & 0.25 & 0.19 \\
\hline Durham & 0.29 & 0.58 & 0.46 & 0.21 & 0.27 & 0.26 \\
\hline Newton Rigg & 0.31 & 0.37 & 0.36 & 0.23 & 0.13 & 0.18 \\
\hline Great Dun Fell & NS & 0.68 & 0.49 & ND & 0.39 & 0.27 \\
\hline \multicolumn{7}{|l|}{ Autumn } \\
\hline Moor House & 0.45 & 0.45 & 0.33 & 0.15 & 0.29 & 0.21 \\
\hline Durham & 0.29 & 0.35 & 0.33 & 0.17 & 0.21 & 0.19 \\
\hline Newton Rigg & 0.32 & NS & $0.24^{*}$ & 0.18 & ND & 0.12 \\
\hline Great Dun Fell & $0.35^{*}$ & 0.89 & 0.49 & 0.12 & 0.24 & 0.20 \\
\hline \multicolumn{7}{|l|}{ Annual } \\
\hline Moor House & 0.34 & 0.54 & 0.56 & 0.24 & 0.33 & 0.25 \\
\hline Durham & 0.56 & 0.69 & 0.63 & 0.28 & 0.27 & 0.27 \\
\hline Newton Rigg & 0.62 & 0.47 & 0.59 & 0.28 & 0.15 & 0.22 \\
\hline Great Dun Fell & 0.78 & 0.85 & 0.86 & 0.35 & 0.34 & 0.37 \\
\hline
\end{tabular}

mouth and the stability at Princetown is that, as for northern Scotland, there was a significant decrease in mean temperature lapse rates between lowland Plymouth and upland Princetown to the north. However, for the shorter 1960-1997 period there was no significant trend in mean temperature lapse rates for the Princetown-Slapton pairing.

\subsection{General implications}

There were significant changes in lapse rates between upland and lowland stations in all study regions. In northern Scotland (data since 1981) and southwest England (data since 1960) there was a significant decrease in the lapse rate for annual mean temperature. In northern England (data since 1959) and central Scotland (data since 1960) there were no significant changes to the annual mean temperature lapse rate between lowland and upland stations. However, there were significant seasonal changes. In northern England, lapse rates for mean temperature significantly declined in the autumn and winter and increased in the spring and summer. Thus, seasons diverged in terms of lapse-rate behaviour. In general, temperature changes were stronger in winter than in the summer and minima rose more than maxima in the uplands, whereas in the lowlands the changes were similar between minima and maxima.

The changes observed suggest that lowland temperature records cannot be used to infer changes in the uplands. This is because of changing seasonal lapse rates. Thus, for countries where the data network is dominated by lowland stations and yet a significant proportion of the landscape is upland, this poses a problem for estimating temperature change over a large proportion of the landscape. In the UK, only $4 \%$ of temperature stations that have ever been operational are located above $300 \mathrm{~m}$ and yet around onethird of the UK's land surface is higher than $300 \mathrm{~m}$. The changes observed also suggest that there may be an extending growing season in some upland areas; this is of enormous policy importance because local food security is actively being discussed among the UK policy community. One scenario of possible near-future UK land management change is intensification of agriculture, wood plantations and energy provision in the uplands (Reed et al. 2009), and this may be aided by ongoing warming and lengthening of the growing season.

Explanations for the observed changes in lapse rates require further research. Holden \& Rose (2010) have shown, based on daily data for Moor House and Durham, that for 4 (out of 27) individual air mass types crossing the UK there have been changes in nearsurface lapse rates. These air flows tended to be those that were westerly or cyclonic and Pepin (2001) has suggested that such changes may be related to warming of North Atlantic sea surface temperatures. Alternatively, Pepin \& Lundquist (2008) have suggested that warming is likely to be more rapid near the $0^{\circ} \mathrm{C}$ isotherm due to snow-ice feedback. This is because warming at this isotherm will lead to a significant reduction in snow and ice cover, a reduction in albedo and, hence, enhanced warming. It is worth noting that, of our upland stations, the mean temperature in the winter was $0.2^{\circ} \mathrm{C}$ at Moor House and $1.0^{\circ} \mathrm{C}$ at Cairngorm chairlift. These were the 2 upland stations where both winter warming and decreased lapse rates were observed. Braemar is the lowest altitude $(339 \mathrm{~m})$ of all our upland stations used for temperature analysis, but the mean winter temperature there was $1.4^{\circ} \mathrm{C}$ and we did observe a slight decrease in winter lapse rates and an increase in summer lapse rates $(p<0.1)$ when compared with lowland Leuchars. Princetown in 
Table 7. Correlation coefficients and gradients of change over time $\left(\mathrm{b},{ }^{\circ} \mathrm{C}\right.$ decade ${ }^{-1}$, or ${ }^{\circ} \mathrm{C}$ decade ${ }^{-1} \mathrm{~km}^{-1}$ for lapse rate) in seasonal and annual mean maxima, mean minima and mean temperature for the southwest England temperature stations. Princetown and Plymouth data are from 1936 to 1997, whereas Slapton data are from 1960 to 1997. Data are significant at $p<0.05$ unless otherwise indicated. ${ }^{*} \mathrm{p}<0.1$; NS: not significant; ND: not determined

\begin{tabular}{|c|c|c|c|c|c|c|}
\hline \multirow[t]{2}{*}{ Station } & \multicolumn{3}{|c|}{$-r$} & \multicolumn{3}{|c|}{$-b$} \\
\hline & Max. & Min. & Mean & Max. & Min. & Mean \\
\hline \multicolumn{7}{|l|}{ Winter } \\
\hline Princetown (upland) & NS & NS & NS & & & \\
\hline Plymouth (lowland) & NS & 0.22 & 0.20 & & 0.09 & 0.08 \\
\hline Slapton (lowland) & 0.34 & NS & 0.41 & 0.34 & & 0.32 \\
\hline Plymouth-Princetown & -0.48 & NS & -0.41 & -1.07 & & -0.62 \\
\hline Slapton-Princetown & NS & NS & NS & & & \\
\hline \multicolumn{7}{|l|}{ Spring } \\
\hline Princetown (upland) & NS & NS & NS & & & \\
\hline Plymouth (lowland) & 0.22 & NS & 0.22 & & & 0.07 \\
\hline Slapton (lowland) & 0.42 & NS & NS & 0.30 & & \\
\hline Plymouth-Princetown & -0.45 & -0.44 & -0.42 & -1.49 & -0.57 & -1.02 \\
\hline Slapton-Princetown & NS & NS & NS & & & \\
\hline \multicolumn{7}{|l|}{ Summer } \\
\hline Princetown (upland) & NS & NS & NS & & & \\
\hline Plymouth (lowland) & $0.19^{*}$ & * NS & NS & & & \\
\hline Slapton (lowland) & 0.34 & NS & 0.38 & 0.32 & & 0.24 \\
\hline Plymouth-Princetown & -0.45 & -0.48 & -0.46 & -2.63 & -1.71 & -2.18 \\
\hline Slapton-Princetown & 0.35 & NS & NS & 0.43 & & \\
\hline \multicolumn{7}{|l|}{ Autumn } \\
\hline Princetown (upland) & NS & NS & NS & & & \\
\hline Plymouth (lowland) & 0.22 & NS & 0.22 & & & 0.07 \\
\hline Slapton (lowland) & NS & NS & 0.33 & & & 0.17 \\
\hline Plymouth-Princetown & -0.48 & -0.34 & -0.49 & -1.93 & -0.84 & -1.56 \\
\hline Slapton-Princetown & NS & NS & NS & & & \\
\hline \multicolumn{7}{|l|}{ Annual } \\
\hline Princetown (upland) & NS & 0.32 & NS & & 0.06 & \\
\hline Plymouth (lowland) & 0.31 & 0.28 & 0.31 & & & 0.07 \\
\hline Slapton (lowland) & 0.46 & 0.34 & 0.55 & 0.27 & 0.15 & 0.25 \\
\hline Plymouth-Princetown & -0.49 & -0.54 & -0.50 & -1.89 & -1.02 & -1.44 \\
\hline Slapton-Princetown & NS & NS & NS & & & \\
\hline
\end{tabular}

\subsection{Changes in rainfall gradients, 1961-2000}

All upland stations except Braemar showed significant increases in winter rainfall over time; this is reflected in significant increases in annual rainfall at Princetown and Burnhope (Table 8). For each station, there were correlations between rainfall (by season and year) and time; in addition, the between-station differences in rainfall were correlated against time, which indicates any differential response over time for one station compared with the other. There was also a significant increase over time in autumn rainfall totals at Princetown. None of the lowland stations showed any significant change in seasonal or annual rainfall totals, except for decreasing summer rainfall at Barrow. For the differences between stations, all pairs except BraemarLeuchars showed highly significant increases in upland rainfall totals in winter compared with changes in the nearby lowlands. This is reflected in differences in annual totals for all these pairs except Malham-Ringway. Therefore, it appears that the strong increase in UK winter rainfall noted by several authors (e.g. Maraun et al. southwest England (453 $\mathrm{m}$ ) is close to the warming effects of the Atlantic Gulf Stream and so the mean winter temperature here was a comparatively mild $3.5^{\circ} \mathrm{C}$, with much less snow cover than for the other upland study stations. Here, we did not observe any changes in upland winter temperatures but we did see a warming in the annual mean minima. Long-term snow cover data are only available from the Moor House station, and here comparison of the 2 snow recording periods (1953-1980 and 1994-2006) indicates a reduction in mean number of days with 'snow lying' from 69 to 41 (Holden \& Rose 2010), which fits with the snow feedback hypothesis. According to Manley (1971), between 1949 and 1970 Moor House had a mean of $72 \mathrm{~d}$ with snow lying, with $106 \mathrm{~d}$ at the Cross Fell station (893 m).
Table 8. Correlation coefficients for rainfall stations with time, 1961-2000. Also shown are the significant correlations with time of the difference between the annual or seasonal rainfall totals for each upland and lowland pair of stations. Data are significant at $\mathrm{p}<0.05$ unless otherwise indicated. NS: not significant

\begin{tabular}{|lccccc|}
\hline \multirow{2}{*}{ Station } & \multicolumn{5}{c}{ Rainfall } \\
\cline { 2 - 3 } & Winter & Spring & Summer & Autumn & Annual \\
\hline Upland station & & & & & \\
Princetown & 0.36 & NS & NS & 0.48 & 0.60 \\
Malham Tarn & 0.41 & NS & NS & NS & NS \\
Coniston & 0.39 & NS & NS & NS & NS \\
Burnhope & 0.47 & NS & NS & NS & 0.41 \\
Braemar & NS & NS & NS & NS & 0.31 \\
Lowland station & & & & & \\
Plymouth & NS & NS & NS & NS & NS \\
Ringway & NS & NS & NS & NS & NS \\
Barrow & NS & NS & -0.32 & NS & NS \\
Durham & NS & NS & NS & NS & NS \\
Leuchars & NS & NS & NS & NS & NS \\
Difference & & & & & \\
Princetown-Plymouth & 0.48 & 0.31 & NS & 0.53 & 0.69 \\
Malham Tarn-Ringway & 0.44 & NS & NS & NS & NS \\
Coniston-Barrow & 0.47 & NS & NS & NS & 0.42 \\
Burnhope-Durham & 0.53 & NS & NS & NS & 0.48 \\
Braemar-Leuchars & NS & NS & NS & NS & NS \\
\hline
\end{tabular}


2008) is amplified in upland areas. Only the Braemar-Leuchars pairing fails to show this differential increase in winter rainfall: there is a tendency for winter rainfall to increase over time at both stations, but in neither case is this significant. It may be that Braemar in the Cairngorms is far enough east and sufficiently in the rain shadow of the Western Highlands to not experience the full effect of the increases in winter rainfall seen further west. Table 9 shows details of the significant correlations for the difference in winter rainfall between the upland and lowland stations. The annual rate of increase ranges from $3.2 \mathrm{~mm}$ $\mathrm{yr}^{-1}$ for Malham-Ringway to $7.2 \mathrm{~mm} \mathrm{yr}^{-1}$ for Coniston-Barrow. For the latter pair, this means that, compared with 1961, Coniston had an additional $288 \mathrm{~mm}$ in winter compared with Barrow by 2000. In other words, compared with the 1961 average winter rainfall at Coniston $(648 \mathrm{~mm})$, there has been a $44 \%$ increase in total winter rainfall, over and above any increase at Barrow. Table 9 also includes altitude-corrected rainfall gradients. These are less easy to interpret than lapse rates because rainfall is more influenced by the general relief around the gauge rather than by gauge altitude per se. Thus, the Barrow-Coniston altitude-corrected gradient appears very high; however, if an effective altitude of $550 \mathrm{~m}$ for Coniston is assumed, as described in Section 2.1 , then the altitiude corrected gradient is $13.4 \mathrm{~mm} \mathrm{yr}^{-1}$ $\mathrm{km}^{-1}$, very similar to the results for other pairings.

Clearly, increases in upland rainfall of this magnitude are very significant for water resource and flood management. The UK receives around $70 \%$ of its drinking water from surface-water resources mainly derived from the uplands. In light of the UK's predicted population growth, the additional rainfall is therefore welcome, but increased storage of this winter rainfall is needed because most of the uplands are covered with peaty soils, which are poor at maintaining baseflow during summer dry spells (Holden \& Burt 2003b). Additional winter rainfall in upland areas may also lead to enhanced flood risk because the peat soils rapidly release most of any heavy rainfall as they have such limited additional storage capacity, with runoff dominated by saturation-excess overland flow (Holden \& Burt 2003a, Holden et al. 2008). Such additional rainfall may also drive increased fluxes of fluvial carbon from the peatlands in the uplands. It has been suggested that discharge is the major control of dissolved organic carbon fluxes from peatlands,

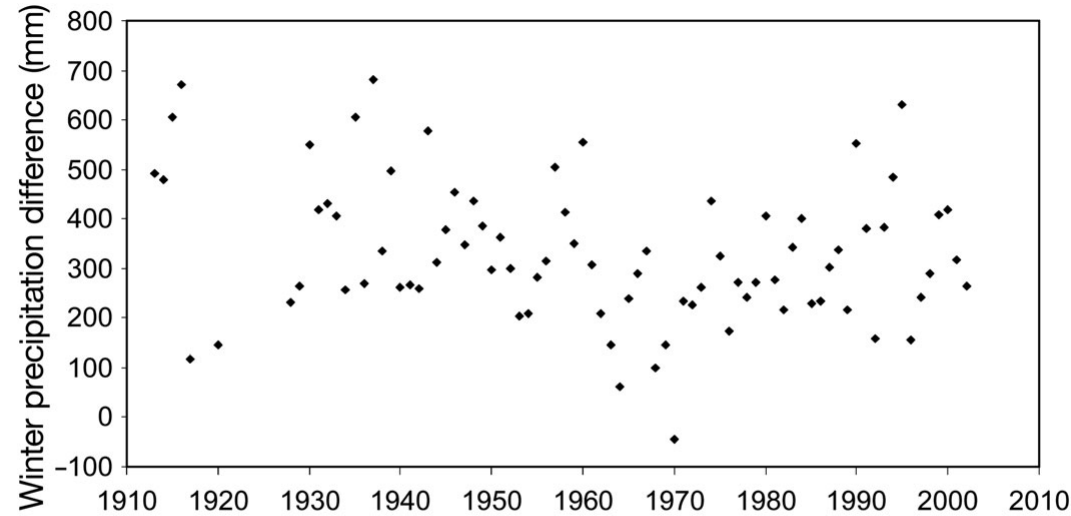

Fig. 5. Difference in winter rainfall $(\mathrm{mm})$ between Princetown (upland) and Plymouth (lowland) which could explain a large proportion of recent increased flux estimates (Worrall et al. 2003, 2009). Similarly, it is likely that discharge acts as a crucial control on particulate carbon fluxes from upland peatlands, particularly in winter when peat may be more susceptible to loosening by freeze-thaw (Holden et al. 2007a) and given that there are large areas of bare peat and open ditches with available sediment for mobilisation (Holden 2005, Holden et al. 2006). However, this effect could be countered by a reduction in freeze-thaw activity associated with warmer conditions in the uplands and the likely impacts on fluvial export of carbon therefore require further research.

Comparison of long-term records for the PrincetownPlymouth pairing shows that the very significant increases in upland winter rainfall since 1960 are not the continuation of a longer trend. There is an apparent decrease from the 1910s to the 1960s (Fig. 5), although this is not statistically significant $(r=-0.15, p=0.37)$. Maraun et al. (2008) argue that, if there has been an increase in winter precipitation intensity across the UK throughout the twentieth century, this would be reflected in seasonal totals. The implication of the results presented here is that this was not initially reflected in the differential response of upland climate; indeed, earlier on, if anything it was the lowlands that became relatively wetter in winter. Only since the 1960s has there 
been significant additional winter rainfall in the uplands; this may be related to the strengthening of the North Atlantic Oscillation (NAO) since the early 1960s (Murphy \& Washington 2001, Fowler \& Kilsby 2002, Osborn \& Hulme 2002).

This interpretation is supported by correlations between the difference between winter rainfall at 4 pairs of stations and the NAO winter index (Hurrell 1995); there was a significant relationship for the period 1961-2000 with r-values of 0.57 for PrincetownPlymouth, 0.61 for Malham Tarn-Ringway, 0.68 for Coniston-Barrow and 0.65 for Burnhope-Durham. There was a strongly significant, positive correlation during this period between the strength of the NAO in winter and the relative increase in upland winter rainfall. A stronger zonal circulation, in effect a stronger westerly air flow, seems therefore to accentuate the orographic effect, giving relatively higher rainfall at greater altitude. Interestingly, at Burnhope, there was a strong, positive correlation for the period 1961-2000 between the number of daily rainfall totals above $15 \mathrm{~mm}$ and the NAO winter index $(\mathrm{r}=0.47)$, implying that the increase in upland rainfall comes in the form of more heavy falls of rain rather than a larger number of smaller events. For the longer time series comparison reported above (Princetown-Plymouth), the correlation between the NAO and the difference in winter rainfall between the 2 stations is also significant $(\mathrm{r}=$ 0.39). Overall, therefore, the Atlantic circulation appears to be a major driver of orographic enhancement in the British uplands, with a more positive index leading to a larger gradient between lowland and upland rainfall totals in winter. It is possible that this reflects both an increase in the frequency of westerly weather types during winter and a change in the characteristics of related air masses, leading to greater rainfall at altitude; this merits further research and analysis.

\section{CONCLUSIONS}

The results of the present study have implications for international research. The results suggest that differences in temperature lapse rates and rainfall gradients with climate change will not be uniform over time or space. The research also shows that analysis of annual trends in lapse rates alone may mask important seasonal trends. This indicates that we cannot use lowland records to infer changes in temperature or rainfall in the uplands, although there is more consistency in the response in relation to rainfall, with differential increases in the uplands in winter being widespread (if not universal) across the UK. For countries where the data network is dominated by lowland stations and yet a significant proportion of the landscape is upland, this poses a problem for estimating temperature or rainfall change over a large proportion of the landscape. In the UK, for example, only $4 \%$ of temperature stations that have ever existed have operated above $300 \mathrm{~m}$ and yet around one-third of the UK's land surface is higher than $300 \mathrm{~m}$.

This paper is novel in its spatial and vertical investigation of recent temperature and rainfall patterns across the UK. Earlier studies of ground-level changes in air-temperature lapse rate in the UK have focused on paired stations in northern England and we have therefore extended the area of observations of uplandlowland lapse-rate change and provided additional temporal data that expand on the time frame of earlier studies (e.g. Pepin 2001). We have observed significant changes in both temperature and rainfall gradients between upland and lowland stations across the UK. The changes were not the same at all stations. The number of upland stations is very limited and thus our choice of stations was restricted to a few suitable upland stations where long-term data were available. Of course it might be that some of our findings result from the particularities of pairs of stations chosen, such as coastal versus inland contrasts, aspect, or the possibility that the northern and southern sides of the Cairngorm Mountains respond differently to the same synoptic change. However, the lack of available upland stations, these possible station contrasts and our findings - which suggest that seasonal changes in the uplands appear to be different to those in the lowlands - suggest that a more intensive long-term climate monitoring network ought to be installed - and maintained - for upland stations. Gauges should be located with reference to topographic gradients and carefully cited with respect to aspect and distance inland. A network could consist of locations covering a range of these variables, but it may be wise to ensure that there are nearby pairs of stations installed with the same topographic position, same distance inland and same aspect to provide calibration for local effects. Whatever the exact design, installing and maintaining a limited number of 'benchmark' stations in the uplands is possibly more important than maintaining a dense network of lowland stations (Burt et al. 2010).

Our research suggests that caution is needed when interpreting annual trends in near-surface lapse rates and rainfall gradients. Changes in temperature and rainfall gradients may be seasonal, such that contrasts between seasons are altered even though no overall change in the annual gradient has been observed. Thus, if results from models are downscaled on the basis of mean annual temperature or rainfall changes, this may mask more important and significant seasonal gradient changes. Better understanding of the links between large-scale circulation patterns and local varia- 
tion in lapse rates could potentially be used to improve the utility of GCM results.

Future temperature and rainfall change in upland areas will be spatially variable. This is because the response of local air-mass types is an important factor, which is affected by the proximity and effects of regional circulation patterns (e.g. NAO). Furthermore, feedbacks related to reduced snow and ice cover from zones with mean winter temperature close to $0^{\circ} \mathrm{C}$ compared with responses in systems with mean temperatures well above or well below freezing mean that spatial variability in lapse-rate change is also highly likely. Thus, we are unlikely to observe consistent changes in near-surface temperature and rainfall gradients across the globe, and patterns are likely to vary regionally and locally. There is therefore a real challenge for the future: to understand such controls on altitudinal temperature and rainfall gradients and their changes within different regions.

Acknowledgements. The work was funded by a Philip Leverhulme Prize awarded to J.H. We are grateful to the Environmental Change Network, the British Atmospheric Data Centre, the University of East Anglia and the Environment Agency for data supplied for this project. We are grateful to those stations that provide data to the British Atmospheric Data Centre for scientific use and, as such, we acknowledge the original sources of those data, including Durham University and Slapton Ley Field Centre (Field Studies Council). NAO Index Data were provided by the Climate Analysis Section, National Center for Atmospheric Research, Boulder, CO (Hurrell 1995).

\section{LITERATURE CITED}

Appenzeller C, Begerta M, Zenklusena E, Scherrerb SC (2008) Monitoring climate at Jungfraujoch in the high Swiss Alpine region. Sci Total Environ 391:262-268

Beniston M, Rebetez M (1996) Regional behavior of minimum temperatures in Switzerland for the period 1979-1993. Theor Appl Climatol 53:231-246

Beniston M, Rebetez M, Giorgi F, Marinucci R (1994) An analysis of regional climate change in Switzerland. Theor Appl Climatol 49:135-159

Black AR, Burns JC (2002) Reassessing the flood risk in Scotland. Sci Total Environ 294:169-184

Bradley RI, Milne R, Bell J, Lilly A, Jordan C, Higgins A (2005) A soil carbon and land use database for the United Kingdom. Soil Use Manage 21:363-369

Burt TP, Horton BP (2001) The natural history of the Slapton Ley National Nature Reserve XXII: the climate of Slapton Ley. Field Stud 10:93-114

Burt TP, Horton BP (2007) Inter-decadal variability in daily rainfall at Durham (UK) since the 1850s. Int J Climatol 27: 945-956

Burt TP, Howden NJK, Worrall F, Whelan MJ (2010) Longterm monitoring of river water nitrate: How much data do we need? J Environ Monit 12:71-79

Christensen JH, Hewitson B, Busuioc A, Chen A and others (2007) Regional climate projections. In: Solomon S, Qin D, Manning M, Chen C and others (eds) Climate change 2007: the physical science basis. Contribution of Working
Group I to the Fourth Assessment Report of the Intergovernmental Panel on Climate Change. Cambridge University Press, Cambridge

Diaz H, Bradley R (1997) Temperature variations during the last century at high elevation sites. Clim Change 36 : 253-279

> Dixon H, Lawler DM, Shamseldin AY (2006) Streamflow trends in western Britain. Geophys Res Lett 33:L19406 doi: 10.1029/2006GL027325

Fowler HJ, Ekström M (2009) Multi-model ensemble estimates of climate change impacts on UK seasonal precipitation extremes. Int J Climatol 29:385-416

- Fowler HJ, Kilsby CG (2002) Precipitation and the North Atlantic Oscillation: a study of climatic variability in Northern England. Int J Climatol 22:843-866

> Fowler HJ, Kilsby CG (2007) Using regional climate model data to simulate historical and future river flows in northwest England. Clim Change 80:337-367

Hannaford J, Marsh TJ (2008) High-flow and flood trends in a network of undisturbed catchments in the UK. Int J Climatol 28:1325-1338

Hilbert DW, Roulet N, Moore T (2000) Modelling and analysis of peatlands as dynamical systems. J Ecol 88:230-242

Holden J (2005) Controls of soil pipe frequency in upland blanket peat. J Geophys Res 110:F01002 doi:10.1029/ 2004JF000143

> Holden J (2007) A plea for more careful presentation of nearsurface air temperature data in geomorphology. Earth Surf Process Landf 32:1433-1436

> Holden J, Burt TP (2003a) Hydrological studies on blanket peat: the significance of the acrotelm-catotelm model. J Ecol 91:86-102

Holden J, Burt TP (2003b) Runoff production in blanket peat covered catchments. Water Resour Res 39:1191 doi:10. 1029/2002WR001956

> Holden J, Rose R (2010) Temperature and surface lapse rate change: a study of the UK's longest upland instrumental record. Int J Climatol doi:10.1002/joc.2136

> Holden J, Evans MG, Burt TP, Horton M (2006) Impact of land drainage on peatland hydrology. J Environ Qual 35: 1764-1778

Holden J, Gascoign M, Bosanko NR (2007a) Erosion and natural revegetation associated with surface land drains in upland peatlands. Earth Surf Process Landf 32:1547-1557

Holden J, Shotbolt L, Bonn A, Burt TP and others (2007b) Environmental change in moorland landscapes. Earth Sci Rev 82:75-100

> Holden J, Kirkby MJ, Lane SN, Milledge DG, Brookes CJ, Holden V, McDonald AT (2008) Overland flow velocity and roughness properties in peatlands. Water Resour Res 44:W06415 doi:10.1029/2007WR006052

Hurrell JW (1995) Decadal trends in the North Atlantic Oscillation: regional temperatures and precipitation. Sci Total Environ 269:676-679

Liu XD, Chen BD (2000) Climatic warming in the Tibetan plateau during recent decades. Int $\mathrm{J}$ Climatol 20: 1729-1742

Malby AR, Whyatt JD, Timmins RJ, Wilby RL, Orr HG (2007) Long-term variations in orographic rainfall: analysis and implications for upland catchments. Hydrol Sci J 52: 276-291

Manley G (1971) The mountain snows of Britian. Weather 26: 192-200

> Maraun D, Osborn TJ, Gillett NP (2008) United Kingdom daily precipitation intensity: improved early data, error estimates and an update from 2000 to 2006. Int J Climatol 28:833-842 
Meehl GA, Stocker TF, Collins WD, Friedlingstein P and others (2007) Global climate projections. In: Solomon S, Qin D, Manning M, Chen C and others (eds) Climate change 2007: the physical science basis. Contribution of Working Group I to the Fourth Assessment Report of the Intergovernmental Panel on Climate Change. Cambridge University Press, Cambridge

Murphy SJ, Washington R (2001) United Kingdom and Ireland precipitation variability and the North Atlantic sealevel pressure field. Int J Climatol 21:939-959

Osborn TJ, Hulme M (2002) Evidence for trends in heavy rainfall events over the UK. Philos Trans R Soc Lond A 360: 1313-1325

Osborn TJ, Hulme M, Jones PD, Basnett TA (2000) Observed trends in the daily intensity of United Kingdom precipitation. Int J Climatol 20:347-364

Pepin NC (1995) The use of GCM scenario output to model effects of future climatic change on the thermal climate of marginal maritime uplands. Geografiska Ann Ser A 77 : 167-185

Pepin NC (2000) Twentieth century change in the climate record for the Front Range, Colorado, USA. Arct Antarct Alp Res 32:135-146

Submitted: January 22, 2010; Accepted: July 8, 2010
Pepin NC (2001) Lapse rate changes in northern England. Theor Appl Climatol 68:1-16

Pepin NC, Lundquist JD (2008) Temperature trends at high elevations: patterns across the globe. Geophys Res Lett 35: L14701 doi:10.1029/2008GL034026

Reed MS, Bonn A, Slee W, Beharry-Borg N and others (2009) The future of the uplands. Land Use Policy S26: S202-S216

Santer BD, Wigley TML, Boyle JS, Gaffen DJ and others (2000) Statistical significance of trends and trend differences in layer-average atmospheric time series. J Geophys Res D 105:7337-7356

> Vuille M, Bradley RS (2000) Mean annual temperature trends and their vertical structure in the tropical Andes. Geophys Res Lett 27:3885-3888

> Worrall F, Burt T, Shedden R (2003) Long term records of riverine carbon flux. Biogeochemistry 64:165-178

> Worrall F, Burt T, Adamson J (2004) Can climate change explain increases in DOC flux from upland peat catchments? Sci Total Environ 326:95-112

- Worrall F, Burt TP, Rowson JG, Warburton J, Adamson JK (2009) The multi-annual carbon budget of a peat-covered catchment. Sci Total Environ 407:4084-4094

Proofs received from author(s): October 27, 2010 